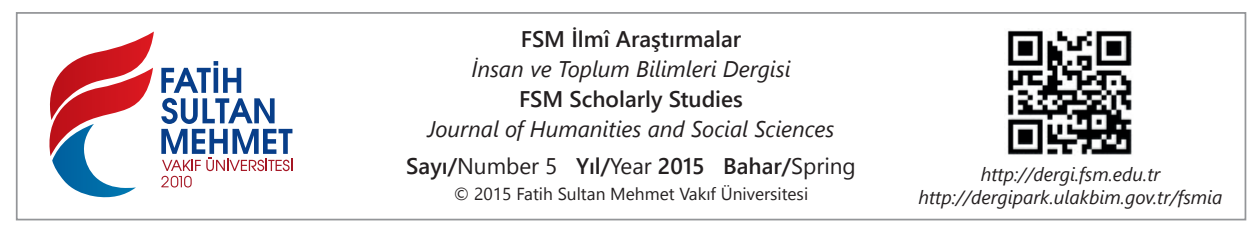

\title{
Tanpınar Literatürüne Bir Değerli Katkı: Şerif Eskin, Zaman ve Hafızanın Kıyısında: Tanpınar'ın Edebiyat, Estetik ve Düşünce Dünyasında Bergson Felsefesi,
} İstanbul: Dergâh Yayınları, 2014, 9789759955410, 231 s. Mehmet Samsakçı*

Ahmet Hamdi Tanpınar, kendisini, beşer(iyet)i, üzerinde yaşadığı toprağ1 ve en geniş mânâsında dünyayı anlamak, tanımak ve duymak isteyenler için (Tanpınar Türkçesi hakkında bir birikim, donanım ve zevk sahibi olmak kaydıyla) vazgeçilmez, tüketilmez bir menbadır. "Benim seviyemden aşağı olanlar beni okumuyorlar, benim seviyemdekiler ise Garbı okuyorlar" dese de Tanpınar, 1970'lerden, özellikle 2000'lerin başından bu yana çok zengin, çok rengîn, çok şey vaad eden bir kıta gibi keşfedildi. Ve kendi tabiriyle söyleyelim, O'na “her zaman bir zengin madene dönülür gibi dönülecektir."

Artık günden günde büyüyen, zenginleşen, bütün dijital imkânlara rağmen takibi imkânsızlaşan değilse bile zorlaşan bir Tanpınar külliyatı, bir Tanpınar edebiyatı, bir Tanpınar literatürü vardır. Tezler, kitaplar, makaleler, denemeler, hatıralar, belgeler... Bu literatürün ne kadarının, ne kadarlık bir ömrü olduğunu, şüphesiz ezelî ve ebedî bir ayıklayıcı, bir süzgeç ve bir filtre olan zaman tayin edecektir.

FSM Vakıf Üniversitesi Edebiyat Fakültesi Türk Dili ve Edebiyatı Bölümü Araştırma Görevlilerinden Şerif Eskin'in başlıkta künyesini verdiğimiz çalışmas1, zamana mukavemet edeceğe benzeyen etütlerden birisi olarak Kasım 2014'te basıldı. İstanbul Üniversitesi Sosyal Bilimler Enstitüsü Türk Dili ve Edebiyatı Anabilim Dalı Yeni Türk Edebiyatı Bilim Dalı bünyesinde Prof. Dr. M. Fatih Andı'nın danışmanlığında hazırlanan yüksek lisans tezinin ${ }^{1}$ gözden geçirilmiş, kitap formatı ve üslûbunda yeniden ele alınmış hâli olan eser, Fransız felsefeci Henry

* Yrd. Doç. Dr., İstanbul Üniversitesi Edebiyat Fakültesi Türk Dili ve Edebiyatı Bölümü, İstanbul/Türkiye, samsakci@istanbul.edu.tr

1 “Ahmet Hamdi Tanpınar'ın Eserleri ve Estetiğinde Bergson Felsefesinin İzdüşümleri ve Kurucu Rolü”, İstanbul, 2012, 211 Y. 
Bergson'dan nasıl, ne oranda etkilendiğini çeşitli eserlerinde cömertçe belirten Tanpınar'ın külliyâtında Bergson düşüncesinin izlerini takip ediyor.

Hıristiyan dünyasının "Şark Meselesi”ni sonuca kavuşturmaya, Türkiye'ninse bir hayat mücadelesini kazanmaya çalıştığı, kafaların karışık, zihinlerin bulanık, millî ve dinî gururun zedelenmiş olduğu 20. asrın ilk çeyreğinde, kalabalık bir dergi- gazete külliyatı içinde bugün bile değerini muhafaza eden bir mecmua yayımlanmıştı: Dergâh. Tanpınar'ın, ismini, kadrosunu, felsefesini, amacını ve değerini cömertçe anlattığ 1 bu mecmua, Yahya Kemal'in, Haşim'in, Yakup Kadri ve Falih Rıfkı'nın, Köprülüzade Mehmed Fuad ve Abdülhâk Şinasi'nin, daha genç nesilden Nurullah Ataç'ın, Necmeddin Halil ve nihayet Tanpınar gibi nevzatların boy gösterdiği, bir kültür-düşünce-edebiyat meraklısını en geniş mânâsında tatmin eden seçkin bir hamleydi. Mustafa Şekip de Bergson'dan yaptığı çevirilerle bu derginin felsefe damarını besliyordu. Birinci Büyük Harp’ten yenik çıkan veya çıkarılan, "insanoğluna bir şeyn olan Mütarekeyi" imzalamak zorunda bırakılan, payitahtı işgal ve izzet-i nefsi rencide edilen, yani madde plânında bozguna uğrayan Türk münevveri bu süreçte mânâya, iç'e, ruh'a yönelmişti. (Söz konusu bu durum, Moğol istilâsı yıllarındaki manevî bereketi ne kadar hatırlatır!) Bütün bir ruh iklimini dolduran metinler, meselâ Erenlerin Bağından, İthaf ya da Rıza Tevfik' in nefesleri bu süreçte intişar etti. Tam bir anti-pozitivist ve anti-materyalist olan; sezgiye, ruha yani bireyin iç âlemine önem veren, rakamları ve köşeli verileri reddeden, nihayet her şeyin "birilerinin dediği şekilde olmak zorunda olmadığını" vurgulayan; izâfiyete yani şahsî tecrübeye inanan Bergson, bu münevver kadro için bulunmaz bir kaynaktı. Eskin'ın çalışmasına eksen olan Tanpınar üzerindeki Bergson etkisi tam da bu dönemde başladı. Tanpınar'ın o yıllarda Bergson'u ne kadar okuduğu ve ne kadar anladığ 1 tartışmalıdır. Fakat Eskin'in de isabetle vurguladığ 1 gibi, etrafta bir Bergson rüzgârı esiyordu, mahfillerde Bergson'un felsefesi konuşuluyordu ve hepsinden önemlisi "mücerret fikirlerdense realite üzerine şahsî sezişle" dursa dahi Bergon'un tefekkürüne çok yakın olan Yahya Kemal, Tanpınar'ın bu yıllarda tek kelime ile "kutbu" idi.

Tanpınar hakkındaki geniş külliyatta Bergson'la ilgili başlıklara rastlamak çok mümkündür. Çeşitli branşlardan yazarlar, çeşitli çap ve hacimlerdeki eserlerinde, Tanpınar üzerindeki Bergson tesirlerini incelemişlerdir. Bununla beraber Eskin, eldeki yerli-yabancı o ağır bibliyografyanın altına girme cesareti göstermiş, sadece edebiyat değil, felsefe, sosyoloji, psikoloji hatta musiki gibi alanlara ait eserleri inceleyerek ve mahallerinde kullanarak doyurucu, düşündürücü, hepsinden önemlisi "tez"ler barındıran sayfalar kaleme almıştır. "Edebiyat ve Felsefe İlişkisi Hakkında" yapılan bir Giriş’ten sonra, "Henri Bergson: Ana Hatlarıyla Eserleri ve Felsefesi", "Bergsonizm ve Türkiye", "Zaman ve Oluş", "Ben, Bilinç ve Hafıza" başlıklı 4 bölümden ve her bölümün gerektirdiği alt başlıklardan olu- 
şan çalışma, Tanpınar'ın eserlerine düşen Bergson gölgesini en anlaşılır ve tatmin edici şekilde ortaya koyan bir plân üzere kaleme alınmıştır.

Bu kitabın bizce mühim tarafı Bergson'un Tanpınar üzerindeki etkisinin sadece "zaman" algısıyla sınırlı kalmadığına, bu etkinin "benlik, bilinç ve hâfıza" gibi çok temel ve hayati alanlara da sirayet ettiğine vurgu yapıyor olmasıdır. Kitabı zengin ve dikkate değer kılan diğer bir noktaysa, bu etkilerin şiir, hikâye, roman gibi belli türlerdeki değil, bütün Tanpınar külliyatı aynasındaki aksinin sorgulanmasıdır. Bu sorgulama ve saptamaların; teklif, tahlil ve tenkitlerin sonraki çalışmalar için önemli bir hamle olduğu şüphesizdir.

Tüm bu noktalar yanında kitapta dikkatimizi çeken birkaç konuyu paylaşalım: Tanpınar araştırıcılarının ve uzmanlarının çok iyi bildiği, yıllardır da “Antalyalı Genç Kız'a Mektup” başlığı altında okuduğu ve kullandığı meşhur mektup, Antalya Lisesi VI Edebiyat C sınıfı öğrencilerinden Mustafa Erol isimli bir delikanlıya yazılmıştır. Prof. Dr. Handan İnci, Tanpınar evrakı içinde yaptığı çalışmalarda bu durumu tespit etmiş, Erol'un 29 Aralık 1961'de yani Tanpınar'ın vefatından birkaç hafta önce yazdığ 1 ikinci mektubu da neşretmişti. ${ }^{2}$ İkinci konu, aslında çok daha temel bir problem olan Tanpınar'ın Bergson okumaları ve etkilenmeler hakkındadır. M. Kayahan Özgül, 2008'de neşrettiği Seke Seke Ben Geldim: Sekmeler 1'de, kendi tabiriyle "ortalığ karıştıracak bir şey" söylemiş ve Tanpınar'ın, Bergson'un Données Immédiats de la Consience'ını hiç okumadığını, "Yekpâre geniş bir ânın / Parçalanmaz akışında" şeklindeki meşhur mısraların aslında Ziya Somar'ın 1939'da yayımladığı Bergson adlı tercüme kitabında yer alan "zamanın bütünlü̈̆̈̈ içinde parçalanmaz bir akışla aktı̆̆ anlar" ifadesinden mülhem olduğunu saptamıştı. ${ }^{3}$ Eskin'in, "Gerçek Zaman Olarak Saf Süre" başlığı altında incelediği ve Tanpınar'ın zaman algısı hakkında bize çok şey söyleyen ve söyleten "Ne İçindeyim Zamanın" başlıklı şiirin çözümlemesinde bu bilgiyi / saptamayı kullanması ya da tartışması bizce kitabın değerini şüphesiz bir kat daha artıracaktı. Bütün bunların yanında bir de teklifimiz var: Tanpınar, çok yönlü, çok katmanlı, kompleks bir yazardır. O ve eserleri hakkında yapılan tespitler daima başkalarını davet eder. Demek istediğimiz şudur ki Tanpınar'ın Bergson'u okuduğu ve O'ndan etkilendiği şüphesizdir. Bununla beraber, Tanpınar aynı zamanda Doğu medeniyetini ve Doğu'nun hikmet dolu geleneğini de tanıyor, Bergson'un 19 ve 20. asırlarda söylediklerinin bazılarının evvelce Doğu'da tartışılmış olduğunu da biliyordu. Öyleyse Tanp1nar'ın "zaman, hâfıza, kimlik vs." konularda söylediklerinin Doğulu referansları araştırılmalı, ortaya konmalıdır. Meselâ

2 “Antalyalı Genç’ten Mektup”, Tanpınar Zamanı: Son Bakışlar, (Haz: Handan İnci), Kapı Yay., İstanbul 2002, s. 317.

3 Hece Yay., İstanbul 2008, s. 21. 
Ne içindeyim zamanın

Ne de büsbütün dişında

Yekpâre geniş bir ânın

Parçalanmaz akışında

ifadelerinin

Ĕgerci sûret-i âhirde geldim âlem-i mülke

Ne mâzîyem ne müstakbel her ânın ânesiyem ben

diyen Nesîmi ile bir irtibatı olup olmadığı sorgulanmalı, burada bir "sosyal genetizm" varsa açığa çıkarılmalıdır.

$* * *$

Doktrin, felsefe, ideoloji, teori gibi temel ve "esas" alanlar, bir yazarın dünyasına, zihnî ve estetik evrenine girmenin vazgeçilmez yollarıdır zira eseri belirleyen, şekillendiren ve yapan, teknik veya metottan önce, persptektiftir. Bu anlamda alttaki fikrî, felsefî ya da hikemî birikimi anlamadan, zihniyeti sorgulamadan yapılacak çalışmalar bir yönüyle eksik kalmaya mahkûmdur. Şu hâlde Şerif Eskin'in çalışmasının, Tanpınar'ın eseri hakkında yapılacak çalışmalar için referans olacak kıratta bir teşebbüs olduğu şüphesizdir. 